\title{
Nota de la redacció
}

Amb aquest número 97/2, la revista PAPERS publica el seu últim volum en paper imprès. D'ara endavant es publicarà exclusivament en format electrònic amb accés obert. Les restriccions pressupostàries que la revista ha d'afrontar han portat l'Equip de Redacció a prendre aquesta decisió, si bé és cert que també s'havia considerat per altres motius (PAPERS ja fa temps que es publica en versió electrònica amb accés obert).

Volem garantir que aquest important canvi, en la línia del que ja han fet altres revistes acadèmiques de prestigi, no afectarà de cap manera la qualitat de la revista. Ben al contrari, en possibilitarà la viabilitat econòmica i ens permetrà concentrar esforços i recursos cada vegada més escassos per impulsar-ne la visibilitat internacional. A més, aquest canvi també garantirà una periodicitat molt més estricta i una agilitat més gran en la gestió i publicació dels manuscrits que arriben a la revista.

En aquest número miscel.lani, podreu trobar-hi un seguit d'articles sobre diversos temes de reflexió teòrica i de recerca empírica en la sociologia actual, a més de la llista d'avaluadors anònims i l'estadística d'articles corresponent a l'any 2011, en compliment dels nostres compromisos de transparència i qualitat editorial. Volem cridar l'atenció sobre el manteniment (i fins i tot el lleuger augment) del percentatge d'articles rebuts el 2011, sobre els quals hem pres una decisió editorial aquest mateix any (més d'un $83 \%$ ), l'augment del nombre d'avaluadors anònims (l'aclaparadora majoria dels quals són externs a la institució editora de PAPERS), i el manteniment d'alts estàndards d'exigència científica pel que fa a les taxes d'acceptació i rebuig d'articles.

No volem desaprofitar l'ocasió per agrair novament el suport de totes les persones que colllaboren amb la revista i la continuen fent possible en aquesta nova etapa. 


\section{Nota de la redacción}

Con el presente número 97/2, la revista PAPERS publica su último volumen en papel impreso. En adelante se publicará exclusivamente en formato electrónico con acceso abierto. Las restricciones presupuestarias que la revista debe afrontar han llevado al Equipo de Redacción a tomar esta decisión, si bien es cierto que se venía sopesando también por otros motivos (PAPERS ya hace tiempo que se publica en versión electrónica con acceso abierto).

Queremos garantizar que este importante cambio, en la línea de lo que han hecho otras revistas académicas de prestigio, no afectará en modo alguno a la calidad de la revista. Bien al contrario, posibilitará su viabilidad económica y nos permitirá concentrar esfuerzos y recursos cada vez más escasos para impulsar su visibilidad internacional. Además, este cambio también garantizará una periodicidad mucho más estricta y una mayor agilidad en la gestión y publicación de los manuscritos que llegan a la revista.

En este número misceláneo se puede hallar una serie de artículos sobre diversos temas de reflexión teórica e investigación empírica en la sociología actual, además del listado de evaluadores anónimos y la estadística de artículos correspondiente al año 2011, en cumplimiento de nuestros compromisos de transparencia y calidad editorial. Queremos llamar la atención sobre el mantenimiento (e incluso el ligero aumento) del porcentaje de artículos recibidos en el 2011, sobre los que hemos tomado una decisión editorial ese mismo año (más de un $83 \%$ ), el aumento del número de evaluadores anónimos (la abrumadora mayoría de los cuales son externos a la institución editora de PAPERS), y el mantenimiento de altos estándares de exigencia científica por lo que respecta a las tasas de aceptación y rechazo de artículos.

No queremos desaprovechar la ocasión para agradecer nuevamente el apoyo de todas las personas que colaboran con la revista y la continúan haciendo posible en esta nueva etapa. 